\title{
Prospects for Using 3D-Printing Technologies in Construction of Buildings in Seismic Areas
}

\author{
Mintsaev M.Sh. \\ Grozny State Petroleum Technical University \\ named M.D. Millionshchikov \\ Grozny, Russia \\ ranas@rambler.ru
}

\author{
Bataev D. K.-S. \\ Complex research Institute named Kh.I. Ibragimov, RAS, \\ Academy of Sciences Chechen Republic, \\ Construction department of Grozny State Petroleum Technical \\ University named M.D. Millionshchikov \\ Grozny, Russia \\ kniiran@mail.ru
}

Mazhiev K. Kh.

Construction department of Grozny State Petroleum Technical University named M.D. Millionshchikov

Material science department

Complex research Institute named Kh.I. Ibragimov, RAS

Grozny, Russia

m.k.kh@mail.ru

Mazhieva A. Kh.

Construction department of Grozny State Petroleum Technical University named M.D. Millionshchikov

Grozny, Russia

a.mazhieva@mail.ru

\author{
Mazhiev Adam Kh. \\ Material science department \\ Complex research Institute named Kh.I. Ibragimov, RAS \\ Department of technical sciences, Academy of Sciences of the \\ Chechen Republic \\ Grozny, Russia \\ adammazhiev@mail.ru \\ Mazhiev Aslan Kh. \\ Complex research Institute named Kh.I. Ibragimov, RAS \\ Department of technical sciences, \\ Academy of Sciences of the Chechen Republic \\ Grozny, Russia \\ aslanmazhiev@mail.ru
}

\author{
Mazhiev M.Kh. \\ Finance University of the Government of the Russian Federation \\ Moscow, Russia \\ adammazhiev@mail.ru
}

\begin{abstract}
The article analyzes innovative construction technology - additive manufacturing - and prospects for using it in the Chechen Republic with complex engineering and geological conditions of construction sites (soil subsidence, high seismicity, etc.). Technologies based on modern composites and traditional materials are analyzed. The article draws conclusions about the possibility of using additive technologies, in particular 3D printing, and building mixtures produced from local natural and man-made materials.
\end{abstract}

Keywords - additive technologies, 3D printing, concrete mix, fiber, construction, reliability, subsidence, seismicity

\section{INTRODUCTION}

Currently, to improve productivity in any area of human activity, it is necessary to use innovative methods and technologies. One of these innovations is production automation. Since the beginning of the twentieth century, it has been used in many areas of production. Implementation of automation in the construction industry was limited by a small quantity of finished products; expensive equipment; special requirements for properties of materials used in automated production [1].

Like any other industry, construction faces low labor productivity, a large number of emergencies, difficult control of construction processes, and a shortage of skilled workers [2]. It is possible to minimize the impact of these factors using $\mathrm{CAD}$ and additive manufacturing (AM).

The history of AM begins in the 1980s when a new method of producing parts was developed. The method is based on a completely new approach - layerwise growing of a product using $\mathrm{CAD}$ models unlike traditional methods of stamping, cutting, forging, etc. (material removal). Since the beginning of AM development, researchers aim to produce non-metallic products or "grow" products from metal powders [3,4] (Fig. 1, 2). 
The main obstacle for implementing additive technologies (AT) in our country is the lack of a legal framework for regulating AM. To some extent, the order of the Federal Agency for Technical Regulation and Metrology No 1013 of September 1, 2015 "On the technical committee on standardization" Additive Technologies" regulates this area [5]. This measure aims to concentrate and coordinate efforts for integrated AT development, including creation of a corresponding system of national standards (classification of materials, requirements for of raw materials quality, structures, technology, equipment, unification of computer model formats).

We have analyzed world experience in development and use of concrete mixtures for using in construction 3D printing.

It is necessary to develop and study new materials used for 3D printing technology. Particular attention should be paid to the potential of local raw materials of the Chechen Republic to use them as complex or individual components of building mixtures. This will give a significant economic effect.

\section{METHODS AND MATERIALS}

At present, researchers reject traditional concepts in construction. New directions focus on additive technologies [6]. Researches which aim to solve problems of construction
3D-printing are carried out in many countries. A number of patents have been issued for new construction mixtures designed for printers [7-10]. In addition to materials, devices and 3D printing technologies are actively patented [11-13].

The next step for improving 3D printing technology was printing of residential houses and building structures (Table 1). It is clear that there are a lot of problems in the construction industry. The construction site is a danger zone.

\section{Key methods of additive production (AP)}

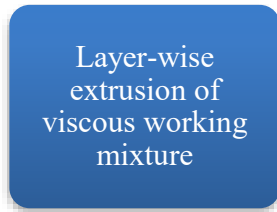

Sintering

method

(selective

sintering)

Spraying method

Метод напыления

(stereolitography)

Fig. 1. Classification of key methods of additive production

\section{Fusing Deposition Modeling, FDM)}

-Layer-wise extrusion of materials through a special nozzle

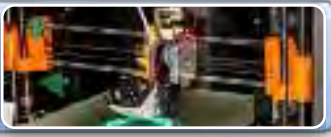

\section{Multi Jet Modeling, MJM}

- Under IR radiation, photopolimers shot from the nozzle in small dozes are polimerized. Printing can be carried out using different materials.

\section{Laminated Object Manufacturing, LOM}

- Thin laminated sheets of the material are cut out using a knife or laser and slittered or patched in a $3 \mathrm{D}$ object.

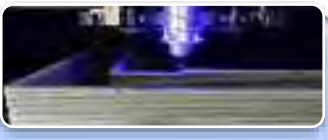

\section{Laser Engineered Net Shaping, LENS}

- Powder is blown out of the nozzle and hits the focused laser beam. A part of the powder flies past, and the part gettinginto the focus of the beam is sintered and forms a threedimensional part.

\section{Stereolitography (StereoLithography Apparatus, SLA)}

- A small bath with liquid polymer is used. The laser beam passes over the surface, and the polymer solidifies under its influence. After one layer is ready, the platform with the part goes down, the liquid polymer fills the void, then the next layer is baked, and so on.

\section{Selective Laser Sintering, SLS}

-It is similar to stereolitography. Instead of liquid photopolymere, powdered sintered with laser is used.

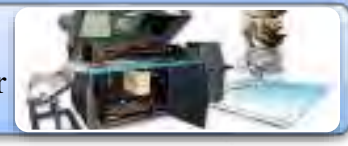

\section{D Printing (3DP)}

- Glue is put on the poweder material and connects granules. Above the glued layer, a new layer of powder is put, etc.
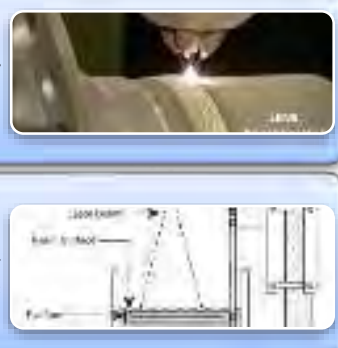

Key additive production technologies. 
When building objects using 3D-technology, the role of a human is minimum. The very fact that a human doesn't take any part in the construction process gives new opportunities. 3D technology is used to construct buildings of simple and complex shapes. One more possibility provided by 3D technology is high construction speed. Using computer modeling, it is possible to lay separate connectors for insulation, piping, electrical wiring and pre-fabricated window blocks. All these elements are identified at the end of 3D printing. A 3D construction printer uses an extrusion technology, according to which each next layer of material used is squeezed out of the printer nozzle over the laid layer along the outline provided by the program, building up the walls. This technology is called FDM (Fused Deposition Modeling).

Using SketchUp, FreeCAD, Blender, OpenSCAD, Rhinoceros, you can specify a 3D-model. A spatial model is exported to a program to form a G-code, and then the information is wire transmitted from a computer to a $3 \mathrm{D}$ printer. The G-code is a trajectory consisting of a set of points of coordinates along which the 3D printer subsequently lays the material which results in growing of an object. POLYGON, CURA, Repetier-Host are used to control the printer [14]. Quick-setting fine-grained concrete reinforced with polymer or steel fiber can serve as a building material for growing bearing elements and structures. Fine-grained concrete lacks coarse aggregate. Other types of cheap concretes modified with additives can be used as well. Conventional cement is not always suitable for manufacturing such products. A universal material which could satisfy all requirements has not been developed yet.

TABLE I. SOME DATA ON OBJECTS AND DEVELOPERS

\begin{tabular}{|c|l|c|c|c|}
\hline $\begin{array}{r}\mathbf{N} \\
\mathbf{o}\end{array}$ & \multicolumn{1}{|c|}{ Object name } & Developer & Location & Year \\
\hline 1. & $\begin{array}{l}\text { Five-storied residential } \\
\text { building }\end{array}$ & Winsun & China & 2014 \\
\hline 2. & Two-storied villa, $1100 \mathrm{~m}^{2}$ & Winsun & China & 2014 \\
\hline 3. & Cement castle & $\begin{array}{c}\text { Total } \\
\text { Kustom }\end{array}$ & $\begin{array}{c}\text { USA, } \\
\text { Minnesota }\end{array}$ & 2014 \\
\hline 4. & Residential building, $165 \mathrm{~m} 2$ & $\begin{array}{c}\text { SPETSAVI } \\
\text { A }\end{array}$ & Russia & 2015 \\
\hline 5. & $\begin{array}{l}\text { Hotel room (Lewis Grand } \\
\text { Hotel, } 130 \mathrm{~m}^{2} \text { ) }\end{array}$ & $\begin{array}{c}\text { Total } \\
\text { Kustom }\end{array}$ & Philippines & 2015 \\
\hline 6. & Office of the future & Winsun & UAE, Dubai & 2016 \\
\hline 7. & Residential building, $38 \mathrm{~m}^{2}$ & APIS COR & Russia & 2017 \\
\hline
\end{tabular}

There are significant drawbacks of materials used in 3Dtechnology-based construction: inability to deliver concrete over a long distance (height) since the mixture hardens in the pipeline; high thermal conductivity (low thermal insulation). Sand or powder modified B60 concretes can be used for 3Dprinting. Such concretes are being developed by Penza State University of Architecture and Construction under the guidance of Professor V.I. Kalashnikov [28], by Grozny State Petroleum Technical University under the guidance of professors D.K.-S. Bataev, S.-A.YU. Murtazaev, and Kh.N. Mazhiev. Their composition has better properties than popular concrete brands. Testing results showed that strength and rheology are better in the samples of fine-grained concretes.

\begin{tabular}{|l|l|}
\hline 1 & $\cdot$ CAD model development \\
\hline 2 & -STL file creation \\
\hline 4 & $\cdot$ Stratification \\
\hline 5 & -3D-printing \\
\hline 6 & - . Stock object processing \\
\hline
\end{tabular}

Fig. 3. Main 3D-printing stages.

It should be noted that cement mixtures with a long setting period (slow hardening) are not suitable for 3D printing [18]. The composition should have thixotropic properties, reduce viscosity under mechanical impact and increase viscosity at rest. One of the ways to solve this problem is to use sulfur-concrete consisting of sulfur and aggregate $[21,22]$. For effective implementation of 3Dprinting, it is necessary to account for two conditions: 1) adhesion coefficient of the layers decreases with an increase in the time interval between growing layers [19]; 2) the material should harden quickly enough to withstand the load of subsequent layers without plastic deformations. The need for withstanding previous layers slows down construction processes.

The combination of these two factors causes inconsistencies in optimizing construction printing. The time interval between two applied layers should not be too short to have time to achieve required strength values, but short to achieve reliable adhesion between the layers [23]. The bearing capacity of the layers depends on the mobility of mixture [20,24]. In layerwise growing of the wall, the lower layer is under the maximum load. To ensure sustainability of the wall, mobility of the concrete mixture must be optimal in order to bear this load.

At the same time, to grow the wall, the required mobility during extrusion and stability after laying should be ensured. This can be achieved by using various superplasticizers. Fiberglass can increase the crack resistance of concrete, since fiber under tensile forces significantly increases performance of the material used for bending and stretching [25-27].

\section{RESULTS}

The analysis of 3D printing technologies in the construction industry shows that researchers have achieved high rates in development of equipment and mixtures for using in mass construction. Of great importance is the fact that traditional sand and fine-grained concretes with various additives can be used as building mixtures: plasticizers, 
hardening accelerators, etc. Production of such building mixtures implies minimum changes in the existing process chain. It makes it possible to select compositions of concrete mixtures and control their properties (strength, stiffness, crack resistance, setting time, etc.) for using in seismic areas.

The use of 3D printing technology is innovative and especially promising in construction of pre-fabricated shelter houses in seismic areas. However, the use of additive technologies raises a number of problems:

1. It is limited in mass construction due to a lack of regulatory and technical basis.

\section{High prices for additive technologies.}

3. Strict requirements for properties of concrete mixtures as far as buildings are located in seismic areas.

At the same time, the use of 3D printing in construction has several advantages:

- high productivity;

- compliance of object parameters to the project;

- easy use;

- low cost of construction objects;

- manual labor automation;

- increased site safety.

\section{CONCLUSION}

Currently, there is a large number of global companies which are developing and successfully using additive technologies for constructing buildings and manufacturing products (Table 1). However, the use of additive technologies at the regional level faces a lot of challenges which require serious researches to solve them.

Among the important problems which influence improvement of construction additive technologies are:

- a lack of regulatory and technical basis,

- need for improving the market of construction mixtures and other materials for 3D-printing,

- $\quad$ high prices for equipment due to a lack of series production.

In our opinion, researches carried out in the Chechen Republic should solve problems arising from the use of additive technologies, improve and adapt equipment to constructed facilities and develop new building mixtures using available local materials.

To make the construction industry use additive technologies, it is necessary to develop a national program to support research and development projects. Grozny State Petroleum Technical University, Complex Research Institute (RAS) and the Academy of Sciences of the Chechen Republic which have research staff and research and technical equipment could play a key role in this process.

\section{References}

[1] Di Carlo T., Khoshnevis B., Carlson A., "Experimental And Numerical Techniques To Characterize Structural Properties Of Fresh Concrete," ASME 2013 International Mechanical Engineering Congress and Exposition. American Society of Mechanical Engineer, pp. V009T10A062-V009T10A062, 2013.

[2] A. Warszawski, R. Navon, "Implementation of robotics in building: Current status and future prospects," Journal of Construction Engineering and Management, No.124 (1), pp. 31-41, 1998.

[3] S.N. Grigoriev, "Problems and prospects of development of national machine-building production," Reference. Engineering Journal with appendix, № 12, 2011.

[4] J.-P. Kruth, M. C. Leu, T. Nakagawa, "Progress in Additive Manufacturing and Rapid Prototyping," Annals of the ClRP. Vol. 47, No. 2, 1998.

[5] Order of the Federal Agency for Technical Regulation and Metrology of September 1, 2015 No 1013 "On the technical committee on standardization" Additive technology "[Electronic resource] // Garant.ru legal information portal. URL: http: // www.garant.ru/products/ipo/prime/ doc / 71074904 / (accessed on 07.10.2018)

[6] Bos F. et al. "Additive manufacturing of concrete in construction: potentials and challenges of 3D concrete printing," Virtual and Physical Prototyping, vol.11, No.3, pp. 209-225, 2016.

[7] L. Xi-Qiang, L. Jing-Fang, Z. Tao, H. Liang, Z. Nan, L. Juan, L. Guoyou. "Cement-based composite material used for 3D printing technology as well as preparation method and application thereof", patent CN104310918A, 2014

[8] Y. Tianrong, L Qiaoling, "3D printing cement-based material and preparation method thereof," patent CN104891891A, 2015

[9] F. Peng, M. Xinmiao. "Fiber reinforced composite material reinforced 3D (three-dimensional) printing structure," patent CN104309126A, 2014

[10] L. Fu-Cai, W. Yi-Yuan, X. Min, L. Bin, Z. Xin-Zhen, H. Ming. "Highperformance powder concrete for 3D (three-dimensional) printing" patent CN104961411A, 2015

[11] Khoshnevis B. "Contour crafting extrusion nozzles", pat. US14/961,071. 2015.

[12] Dini E. "Method for automatically producing a conglomerate structure and apparatus therefor," pat. US8337736. 2012.

[13] Dini E., Chiarugi M., Nannini R. "Method and device for building automatically conglomerate structures," pat. 11/908,993 SShA. 2006.

[14] Grakhova E.V. "The use of modern educational technology in the educational process", Technical universities: integration with European and world educational systems: Proceedings of the VI International Conference. pp. 96-99, 2014.

[15] H.N. Mazhiev, D.K-S. Batayev, M.A. Gaziev, K.Kh. Mazhiev, A.Kh Mazhieva, "Materials and structures for construction and reconstruction of buildings and structures in seismic areas", Grozny, 2014.

[16] D. K.S. Bataev, M. A. Gaziev, Adam Kh. Mazhiev, Aslan Kh. Mazhiev, "Investigation of the Properties of New Surface-Active Additives for Concretes", Materials Science Forum, Vol. 931, pp. 544547, 2018.

[17] Murtazaev, S.-A., Kuladzhi, T., Mintsaev, M., Aliev, S. "Peculiarities of helio-termal treatment of reinforced concrete structures in the conditions of extreme north", International Journal of Environmental and Science Education, 11 (18), pp. 12753-12762, 2016.

[18] L. Xi-Qiang, L. Jing-Fang, Z. Tao, H. Liang, Z. Nan, L. Juan, L. Guoyou. "Cement-based composite material used for 3D printing technology as well as preparation method and application thereof," pat. CN104310918A. 2014

[19] Lloret E. et al. "Complex concrete structures: Merging existing casting techniques with digital fabrication", Computer-Aided Design, No.60. pp. 40-49, 2016. 
[20] Le T. T. et al. "Mix design and fresh properties for high-performance printing concrete", Materials and structures, vol. 45, No. 8, pp. 12211232, 2015.

[21] Grugel R. N., Toutanji H. "Sulfur "concrete" for lunar applicationsSublimation concerns", Advances in Space Research, vol. 41, No. 1, pp. 103-112, 2008.

[22] Hager I., Golonka A., Putanowicz R. "3D printing of buildings and building components as the future of sustainable construction?", Procedia Engineering, No. 151, pp. 292-299, 2016.

[23] Le T.T. et al. "Hardened properties of high-performance printing concrete," Cement and Concrete Research, vol. 42, No. 3, pp. 558-566, 2012.

[24] Perrot A., Rangeard D., Pierre A. "Structural built-up of cement-based materials used for 3D-printing extrusion techniques"”, Materials and Structures, vol. 49, No. 4, pp. 1213-1220, 2016.
[25] Serykh I. R., Panchenko L. A. "Prochnost steklofibrobetona", Nauchnyye trudy Sworld, vol. 9, No. 2, pp. 43-47, 2012.

[26] Kim G. B., Pilakoutas K., Waldron P. "Development of thin FRP reinforced GFRC permanent formwork systems", Construction and Building Materials, vol. 22, No. 11, pp. 2250-2259, 2008.

[27] M. Yi. 3D (Three-Dimensional) printing high-strength composite board: pat. CN 104328890 A. 2014

[28] [28] N.I. Vatin, L.I. Chumadov, I.S. Goncharov, V.V. Zykova, Karpena A.N., Kim A.A., Finashenkov E.A. "3D printing in construction", Construction of unique buildings and structures, No.1 (52), pp. 27-46, 2007 